\title{
Levels of Some Trace Metals in Fishes Tissues, Water and Sediment at Tendaho Water Reservoir, Afar Region, Ethiopia
}

Wondimagegne Asefa ${ }^{1,2 *}$ and Tarekegn Beranu ${ }^{1,3}$

${ }^{1}$ School of Postgraduate Program, Department of Chemistry, Ambo University, Ethiopia

${ }^{2}$ Department of Chemistry, Samara University, Ethiopia

${ }^{3}$ Ethiopian Quality Control Authority, Addis Ababa, Ethiopia

\begin{abstract}
The levels of trace metals ( $\mathrm{Cd}, \mathrm{Co}, \mathrm{Cu}, \mathrm{Mn}, \mathrm{Fe}, \mathrm{Pb}, \mathrm{Zn}, \mathrm{Cr}$ and $\mathrm{Ni}$ ) in three commercially important fish tissues and their environment of a newly constructed manmade dam, Tendaho reservoir, investigated using validated analytical method under appropriate quality control measures. The analysis result of samples after wet digestion with flame atomic absorption spectroscopy showed that excluding $\mathrm{Zn}, \mathrm{Mn}$ and $\mathrm{Co}$ (fishes tissue>sediment>water) metals distribution in fishes tissue and their environment existed in the order of: sediment>fishes tissue>water. In fish species regardless of the type, the levels of almost all metals were higher in detoxification organs (gill and liver) than in muscle. Higher values of calculated bioconcentration factor and two-way ANOVA analysis result $(P$-value $<0.05)$ also indicated that the highest level of majority metals existed in Catfish in compared to Tilapia and Barbus intermedius. The concentrations of $\mathrm{Mn}, \mathrm{Fe}$, $\mathrm{Pb}$ and $\mathrm{Cr}$ were higher than Ethiopian Environmental Protection Authority (2003) guidelines in water while the levels of all metals were below PEL guidelines of USEPA (2000) for sediment. Safety of customers from trace metal pollution hazard from fishes was indicated by low level of calculated hazard quotient and comparisons result with WHO (1989) and USFDA (1993) guideline values.
\end{abstract}

Keywords: Biococentration factor; Hazard quotient; Safety of customers; Guidelines Awash River

\section{Introduction}

Following the recent urbanization and economic developments in Africa, environmental pollution has increased [1]. This makes African aquatic environments as final sinks for trace metal pollutants originated from agricultural and industrial activities and spillage of leaded gasoline from watercrafts $[2,3]$.

Although Ethiopia does not have the industry that flourished in developed countries and thus pollutants are not produced in large quantities, pollution due to human activities and by natural inorganic chemicals cause many changes in the aquatic environment as observed in many rift valley water bodies $[4,5]$. To prevent pollution disaster like Minamata disease that occurred in Japan by $\mathrm{Hg}$ and $\mathrm{Cd}$ poisoning, continuous follow up and monitoring of environmental pollutants is mandatory [6,7].

Awash River is major water sources of Tendaho reservoir. The river flows from central highlands through Ethiopia's major industrial and agro-industrial belt. Pollutants from suburb of Addis Ababa and other cities enter Awash River carrying the whole burden of all types of raw effluents from industrial and agricultural sources. The reservoir is located in very hot area with average temperature ranging from above $28.5^{\circ} \mathrm{C}$ where evapo-transpiration greatly exceeds mean annual rainfall that leads to the accumulation of salts on surface soil from the ground water and closeness to Ethiopia-Djibouti rides of highway also increases concentration of salt and toxic elements.

In fresh water environment trace metals are potentially accumulated in sediments and marine organisms and subsequently transferred to man through the food chain. Their concentrations in aquatic ecosystems are usually monitored by measuring their concentrations in water, sediments and biota [8]. To look into the current trace metals pollution status of the area and commercially important fishes (Tilapia,
Catfish and Barbus), this study was conducted. This is important to prevent trace metal pollution disaster like Minamata disease and for better utilization of the potentially rich man-made lake.

\section{Materials and Methods}

\section{Description of the study area}

The study was conducted in Tandaho water reservoir in Afar Regional State, Ethiopia, located in the Northern part of the Ethiopian Rift Valley (Figure 1). It is situated at $11^{\circ} 40^{\prime} 786^{\prime \prime N}$; $40^{\circ} 57^{\prime} 486^{\prime \prime} \mathrm{E}$ about $580 \mathrm{Km}$ east of the capital city, Addis Ababa.

\section{Materials and equipments}

Materials and equipments used were: plastic bucket, gill nets, plastic meat chopper, plastic knives, ice box, crucibles, drying oven (DHG9070A, India), electronic analytical balance with $0.0001 \mathrm{~g}$ accuracy (AA-200DS, Deriver Instrument Company), safety hood (ESCO, Singapore) and flame atomic absorption spectrophotometer (ELICO SL-194, India) equipped with deuterium background corrector and an air/acetylene flame atomizer.

\section{Chemicals and reagents}

Chemicals and reagents, concentrated hydrochloric acid, concentrated perchloric acid, concentrated nitric acid and hydrogen

*Corresponding author: Wondimagegne Asefa, Department of Chemistry, Samara University, Po.Box: 132, Ethiopia, Tel: +251911086413; E-mail: wondimagegneams@yahoo.com

Received May 12, 2015; Accepted July 29, 2015; Published August 04, 2015

Citation: Asefa W, Beranu T (2015) Levels of Some Trace Metals in Fishes Tissues, Water and Sediment at Tendaho Water Reservoir, Afar Region, Ethiopia. J Environ Anal Toxicol 5: 313. doi:10.4172/2161-0525.1000313

Copyright: ( 2015 Asefa W, et al. This is an open-access article distributed under the terms of the Creative Commons Attribution License, which permits unrestricted use, distribution, and reproduction in any medium, provided the original author and source are credited. 
peroxide purchased from UNI Chem Qualikems, India. Standard solutions and spiked standard solutions were prepared from $1000 \mathrm{ppm}$ stock solutions of $\mathrm{Pb}$ (Pura tronic Afa Aesan Johnso Mathey Company, Germany), Ni, Cd (both Aldrich-Germany), Fe (PS Pank Scientific limited, UK), Zn, Cu (both Fluka, Switzerland), Mn and Co (both Win Lab-UK).

\section{Preparation of sampling equipments}

All sampling materials, samples holders and fish dissecting materials were washed with metal free Liquinox detergent, rinsed with distilled water, soaked with $20 \%(\mathrm{v} / \mathrm{v})$ nitric acid for two days, re-rinsed with deionized water and air dried. These cleaned and dried materials were used to collect the required samples.

\section{Convenient site selection for sampling at reservoir}

Twelve stations were selected around all parts of the reservoir for water and sediment sampling and at the same time fishes were collected around water and sediment sampling sites. Again at three equidistant sites field blanks were kept (Figure 1).

\section{Water sampling and transportation}

Around twelve liters of water sample were collected at selected sites by using jug and bottles into a bucket. Thoroughly mixing collected sample three liters of composite water sample was filtered by $0.45 \mu \mathrm{m}$ filter paper and acidified by $\mathrm{HNO}_{3}$ to $\mathrm{pH}<2$ in polyethylene bottle. The acidified sample in polyethylene bottles was kept in ice box and sample holding ice box was transported to the laboratory.

\section{Sediment sampling and transportation}

As reservoir has rapids and falls, following $[9,10]$ sediment sampling and analysis methods around ten kilograms of sediment was collected from beneath an aqueous layer. From collected samples stones, gravels, plant materials and shells were removed. After thoroughly homogenizing the remaining sample by cone formation around $3.0 \mathrm{~kg}$ of composite sample was transferred to pre- cleaned polyethylene plastic bag. Keeping the plastic bag in ice box the sample was transported to laboratory.

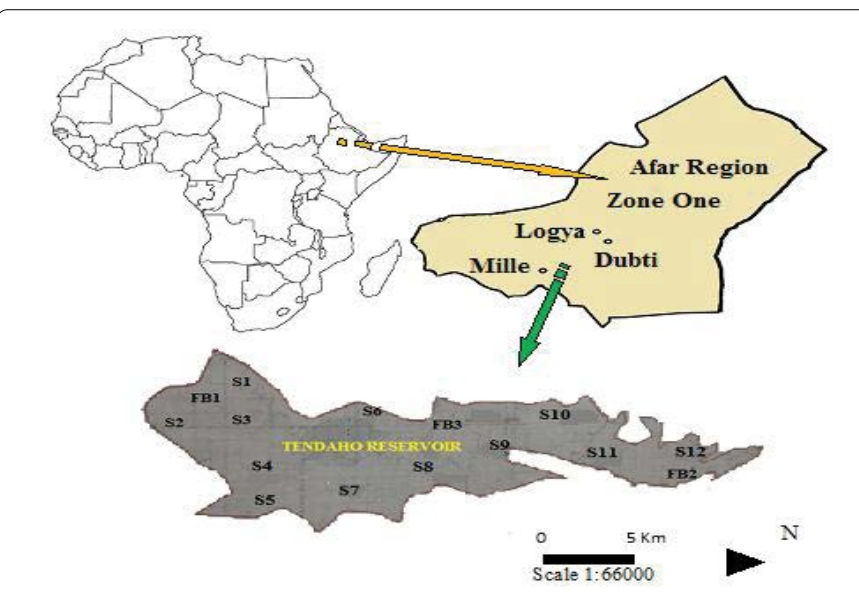

Figure 1: Graphical locations and sites of sample collecting areas Where: $\mathrm{S}=$ sampling site and $\mathrm{FBL}=$ field blank placed area

\section{Fish sampling and transportation}

To get around $200 \mathrm{~g}$ composite fish tissue from each species in accordance with [11] method of fish sampling and analysis, Ten Tilapias (Oreochromis niloticus), fifteen Barbus (Barbus intermedius) and eight Catfishes(Clarias gariepinus), were caught with gillnets in Winter season. The collected fish samples were dissected with plastic knives on plastic meat chopper carefully. The composite samples of each fish muscles, gills and livers were transferred to labeled plastic bags and the plastic bags and their contents were kept in ice box and transported to laboratory.

\section{Sample preparation}

For fish sample preparation optimized procedure adopted by Kebede and Wondimu was used. In digestion procedure $1.0 \mathrm{~g}$ muscle or $0.5 \mathrm{~g}$ gill/liver was placed in $125 \mathrm{~mL}$ beaker and by $6 \mathrm{~mL} \mathrm{HNO}_{3}$ and $2 \mathrm{~mL} \mathrm{HClO}_{4}$ were added and the mixture was heated at $180^{\circ} \mathrm{C}$ for 90 minutes in watch glass closed beaker. After 115 min of digestion colorless digestate and its respective washing was transferred to $25 \mathrm{~mL}$ volumetric flask and diluted to the mark by deionized water for FAAS analysis.

Water sample was digested by optimized procedure [12]. In the procedure $100 \mathrm{~mL}$ aliquot of representative water sample was placed in $150 \mathrm{~mL}$ beaker and $3 \mathrm{~mL}$ of $\mathrm{HNO}_{3}$ was added then digestion continued in watch glass closed beaker for 1 hour at $120^{\circ} \mathrm{C}$; after 5 min cooling extra $3 \mathrm{~mL} \mathrm{HNO}_{3}$ was added and digestion continued for $40 \mathrm{~min}$ at $180^{\circ} \mathrm{C}$ again after another 5 min cooling by adding $10 \mathrm{~mL} 1: 1 \mathrm{HCl}$ to dissolve silicates from resulting digestate digestion continued for $20 \mathrm{~min}$ at $240^{\circ} \mathrm{C}$. After $130 \mathrm{~min}$ beaker walls and watch glasses were washed with deionized water and the resulting washings were filtered to remove silicates and other insoluble materials that could clog the nebulizer. Finally the filtrate was transferred to $100 \mathrm{~mL}$ volumetric flask and diluted to the mark by deionized water for AAS analysis.

Optimizing the procedure adopted by Tolla digestion of sediment was carried out. In working procedure $0.5 \mathrm{~g}$ sieved grains of sediment sample was placed in $100 \mathrm{~mL}$ Erlenmeyer flask and $6 \mathrm{~mL} \mathrm{HNO}_{3}$ and 2 $\mathrm{mL} \mathrm{HClO}_{4}$ was added. The resulting mixture was heated for $105 \mathrm{~min}$ at $180^{\circ} \mathrm{C}$. After $5 \mathrm{~min}$ of cooling $3 \mathrm{~mL} \mathrm{H}_{2} \mathrm{O}_{2}$ was added and heating continued for $10 \mathrm{~min}$ at $240^{\circ} \mathrm{C}$. The digestate produced by the procedure was dissolved in $10 \mathrm{~mL} 30 \% \mathrm{HNO}_{3}$ and filtered using $0.45 \mu \mathrm{m}$ Whatman filter paper to remove silicate residue. Then, the filtrate was diluted to $50 \mathrm{~mL}$ by $3 \% \mathrm{HNO}_{3}$ in volumetric flask for FAAS analysis.

\section{Quality control measures}

Samples were prepared after verifying the methods were applicable for their intended purposes. Determined analytical methods validation criteria were: method detection limit almost less than $0.01 \mu \mathrm{g} / \mathrm{g}$ (fish and sediment sample) and $\mu \mathrm{g} / \mathrm{mL}$ for water sample; matrix dependent accuracy $(\% \mathrm{R}=84.18-102.52)$ and precision $(\mathrm{RPD}=1.02-13.85)$; repeatability with RSD below $5 \%$ and within lab reproducibility was also with RSD was all below $10 \%$ for all samples of each metal. This is an indication of practical utility of the method for trace metal analysis [12-14].

Sample prepared by optimized and validated procedures was analyzed by constant evaluations of quality of the result generated by quality control sample analysis. To control the performance of 
Citation: Asefa W, Beranu T (2015) Levels of Some Trace Metals in Fishes Tissues, Water and Sediment at Tendaho Water Reservoir, Afar Region, Ethiopia. J Environ Anal Toxicol 5: 313. doi:10.4172/2161-0525.1000313

Page 3 of 6

optimized instrumental conditions and validated analytical method throughout; analysis of instrument quality control samples (IQCS) and method quality control samples (MQCS) were done. From experimental results and based on $[12,13,15]$ all quality control sample analysis results were acceptable. In addition absence of field sample contamination was observed from analysis results of field black which has readings below method detection limits for all metals. Therefore, analytical results generated during this study can be used for decision making.

\section{Human and fish risk assessment analysis}

The human risk assessment was indicated by calculated hazard quotient (HQ). To calculate it estimated daily intake (EDI) was calculated by taking $200 \mathrm{~g}$ /year of Ethiopians fish consumptions [16] and the average body weight of Ethiopian as $55 \mathrm{Kg}$ using following equation:

$$
E D I=C x \frac{D F_{a v}}{B W_{a v}}
$$

Where: $\mathrm{C}=$ average dry weight concentration of metals in fish filet

$$
\mathrm{D}_{\mathrm{Fav}}=\text { Daily avenge fish consumption of Ethiopian }
$$$$
\mathrm{B}_{\mathrm{Wav}}=\text { Average body weight of Ethiopian }
$$

From above calculated EDI and by reference dose (RfD) established [13] HQ was calculated using:

$$
H Q=\frac{E D I}{R f D}
$$

Fish risk assessment was done by calculating bioconcentration factor (BCF) from average concentration in organism tissue and concentration in water using following equation:

$$
B C F=\frac{C f}{C m}
$$

Where $\mathrm{Cf}=$ average dry weight concentration of metals in fish filet

$$
\mathrm{Cm}=\text { average wet weight concentration of metals in water }
$$

\section{Results and Discussions}

\section{Moisture content of fish}

Total moisture content of fish tissue was determined by procedures [17]. The results obtained are shown in Table 1 below as percentage of moisture content.

From Table 1, fish moisture content varied in the order: Tilapia $>$ Barbus $>$ Catfish in muscle and gill tissues. While in liver the order is: Tilapia $>$ Catfish $>$ Barbus. This is an indication for the presence of higher levels of lipids or proteins in muscles of Catfishes as compared to the other species [18].

\begin{tabular}{|c|c|c|}
\hline Fish species & Tissue & \% moisture content $\mathbf{( n = 3 )}$ \\
\hline \multirow{3}{*}{ Tilapia } & Muscle & $83.84 \pm 0.03$ \\
\cline { 2 - 3 } & Gill & $82.86 \pm 0.71$ \\
\cline { 2 - 3 } & Liver & $78.22 \pm 0.38$ \\
\hline \multirow{3}{*}{ Barbus } & Muscle & $77.93 \pm 0.01$ \\
\cline { 2 - 3 } & Gill & $71.02 \pm 0.16$ \\
\cline { 2 - 3 } & Liver & $70.56 \pm 0.96$ \\
\hline \multirow{3}{*}{ Catfish } & Muscle & $70.04 \pm 0.01$ \\
\cline { 2 - 3 } & Gill & $70.29 \pm 0.29$ \\
\cline { 2 - 3 } & Liver & $75.25 \pm 0.20$ \\
\hline
\end{tabular}

\begin{tabular}{|c|c|c|c|c|}
\hline \multirow{2}{*}{ Fishes } & \multirow{2}{*}{ Metals } & \multicolumn{3}{|c|}{ Tissues } \\
\hline & & Muscle & Gill & Liver \\
\hline \multirow{9}{*}{$\begin{array}{l}\text { C } \\
\text { A } \\
\text { T } \\
\text { F } \\
\text { I } \\
\text { S } \\
\text { H }\end{array}$} & $\mathrm{Cd}$ & $0.31 \pm 0.01$ & $0.84 \pm 0.06$ & $0.41 \pm 0.03$ \\
\hline & Co & $3.65 \pm 0.03$ & $7.05 \pm 0.06$ & $5.28 \pm 0.25$ \\
\hline & $\mathrm{Cu}$ & $2.53 \pm 0.03$ & $4.04 \pm 0.08$ & $3.29 \pm 0.05$ \\
\hline & $\mathrm{Mn}$ & $3.82 \pm 0.04$ & $5.16 \pm 0.23$ & $7.90 \pm 0.29$ \\
\hline & $\mathrm{Fe}$ & $55.12 \pm 1.13$ & $31.52 \pm 1.19$ & $71.55 \pm 1.38$ \\
\hline & $\mathrm{Pb}$ & $0.73 \pm 0.03$ & $5.16 \pm 0.12$ & $3.42 \pm 0.05$ \\
\hline & $\mathrm{Zn}$ & $32.29 \pm 1.12$ & $41.84 \pm 1.16$ & $53.87 \pm 1.5$ \\
\hline & $\mathrm{Cr}$ & $0.76 \pm 0.02$ & $1.46 \pm 0.06$ & $0.83 \pm 0.04$ \\
\hline & $\mathrm{Ni}$ & $2.17 \pm 0.13$ & $3.21 \pm 0.03$ & $2.73 \pm 0.03$ \\
\hline \multirow{9}{*}{$\begin{array}{l}\mathrm{T} \\
\mathrm{I} \\
\mathrm{L} \\
\mathrm{A} \\
\mathrm{P} \\
\mathrm{I} \\
\mathrm{A}\end{array}$} & $\mathrm{Cd}$ & $0.23 \pm 0.01$ & $0.51 \pm 0.01$ & $0.32 \pm 0.02$ \\
\hline & Co & $3.18 \pm 0.07$ & $4.63 \pm 0.03$ & $5.15 \pm 0.04$ \\
\hline & $\mathrm{Cu}$ & $2.13 \pm 0.03$ & $3.12 \pm 0.02$ & $3.54 \pm 0.04$ \\
\hline & $\mathrm{Mn}$ & $4.23 \pm 0.03$ & $3.61 \pm 0.02$ & $6.28 \pm 0.05$ \\
\hline & $\mathrm{Fe}$ & $24.98 \pm 1.27$ & $22.26 \pm 1.22$ & $37.96 \pm 1.14$ \\
\hline & $\mathrm{Pb}$ & $0.52 \pm 0.01$ & $3.34 \pm 0.04$ & $2.45 \pm 0.03$ \\
\hline & $\mathrm{Zn}$ & $21.74 \pm 1.01$ & $34.56 \pm 1.24$ & $27.62 \pm 1.01$ \\
\hline & $\mathrm{Cr}$ & $0.53 \pm 0.01$ & $1.05 \pm 0.05$ & $0.73 \pm 0.03$ \\
\hline & $\mathrm{Ni}$ & $1.87 \pm 0.12$ & $1.42 \pm 0.12$ & $2.06 \pm 0.05$ \\
\hline \multirow{9}{*}{$\begin{array}{l}B \\
A \\
R \\
B \\
U \\
S\end{array}$} & $\mathrm{Cd}$ & $0.18 \pm 0.01$ & $0.24 \pm 0.01$ & $0.16 \pm 0.01$ \\
\hline & Co & $2.21 \pm 0.04$ & $4.43 \pm 0.03$ & $6.20 \pm 0.04$ \\
\hline & $\mathrm{Cu}$ & $1.26 \pm 0.02$ & $2.32 \pm 0.03$ & $2.23 \pm 0.02$ \\
\hline & $\mathrm{Mn}$ & $2.11 \pm 0.01$ & $4.62 \pm 0.05$ & $3.27 \pm 0.03$ \\
\hline & $\mathrm{Fe}$ & $18.27 \pm 0.24$ & $15.13 \pm 0.30$ & $25.07 \pm 1.03$ \\
\hline & $\mathrm{Pb}$ & $0.33 \pm .01$ & $0.84 \pm 0.04$ & $0.41 \pm 0.02$ \\
\hline & $\mathrm{Zn}$ & $12.60 \pm 0.06$ & $15.76 \pm 0.08$ & $13.58 \pm 0.05$ \\
\hline & $\mathrm{Cr}$ & $0.25 \pm 0.02$ & $0.74 \pm 0.01$ & $0.81 \pm 0.02$ \\
\hline & $\mathrm{Ni}$ & $1.23 \pm 0.04$ & $2.14 \pm 0.01$ & $1.56 \pm 0.07$ \\
\hline
\end{tabular}

Table 1: Total moisture content of fish tissue (muscle, gill and liver) of each fish.

\begin{tabular}{|c|c|c|}
\hline \multirow{2}{*}{ Metals } & \multicolumn{2}{|c|}{ Samples } \\
\cline { 2 - 3 } & Water & Sediment \\
\hline $\mathrm{Cd}$ & $<\mathrm{MDL}$ & $1.03 \pm 0.03$ \\
\hline $\mathrm{Co}$ & $1.23 \pm 0.04$ & $2.59 \pm 0.05$ \\
\hline $\mathrm{Cu}$ & $0.53 \pm 0.03$ & $10.35 \pm 0.52$ \\
\hline $\mathrm{Mn}$ & $0.86 \pm 0.04$ & $3.28 \pm 0.18$ \\
\hline $\mathrm{Fe}$ & $1.32 \pm 0.07$ & $102.13 \pm 1.30$ \\
\hline $\mathrm{Pb}$ & $0.26 \pm 0.02$ & $5.78 \pm 0.15$ \\
\hline $\mathrm{Zn}$ & $2.51 \pm 0.10$ & $21.89 \pm 1.22$ \\
\hline $\mathrm{Cr}$ & $0.15 \pm 0.01$ & $2.52 \pm 0.06$ \\
\hline $\mathrm{Ni}$ & $0.95 \pm 0.04$ & $5.24 \pm 0.24$ \\
\hline
\end{tabular}

Table 2: Levels of trace metals (average $\pm S d, n=3$, in $\mu \mathrm{g} / \mathrm{g}$ for sediment and $\mathrm{mg} / \mathrm{L}$ for water) in Tendaho reservoir sediment and water samples.

Table 3: Levels of trace metals (average $\pm S d, n=3$, in $\mu \mathrm{g} / \mathrm{g}$, dry weight) in commercially important fishes' tissue of Tendaho reservoir.

\section{Levels of trace metals determined from samples}

The mean concentrations of sediment $(\mu \mathrm{g} / \mathrm{g})$ and water $(\mathrm{mg} / \mathrm{L})$ (Table 2) clearly indicate that levels of trace metals in sediment sample is higher than water sample irrespective of the metal type. Whereas, the relative amount of the metals in water sample is in the order: $\mathrm{Zn}>\mathrm{Fe}>$ $\mathrm{Co}>\mathrm{Ni}>\mathrm{Mn}>\mathrm{Cu}>\mathrm{Pb}>\mathrm{Cr}>\mathrm{Cd}$ and in sediments the order is: $\mathrm{Fe}>$ $\mathrm{Zn}>\mathrm{Cu}>\mathrm{Ni}>\mathrm{Pb}>\mathrm{Mn}>\mathrm{Co}>\mathrm{Cr}>\mathrm{Cd}$.

Tabulated data in Table 3 clearly indicates that metals existed in the order: (i). In Catfish: Gill > liver > muscle for $\mathrm{Cd}, \mathrm{Co}, \mathrm{Cu}, \mathrm{Pb}, \mathrm{Cr}$ and $\mathrm{Ni}$; liver $>$ gill $>$ muscle for $\mathrm{Mn}$ and $\mathrm{Zn}$ and liver $>$ muscle $>$ gill for $\mathrm{Fe}$. (ii). In Tilapia: gill $>$ liver $>$ muscle for $\mathrm{Cd}, \mathrm{Zn}, \mathrm{Pb}$ and $\mathrm{Cr}$; liver $>$ gill $>$ muscle for $\mathrm{Co}$ and $\mathrm{Cu}$ and liver $>$ muscle $>$ gill for $\mathrm{Mn}, \mathrm{Fe}$ and Ni. (iii). 
In Barbus: gill $>$ liver $>$ muscle for $\mathrm{Cu}, \mathrm{Mn}, \mathrm{Pb}, \mathrm{Zn}$ and $\mathrm{Ni}$; liver $>$ gill $>$ muscle for $\mathrm{Co}$ and $\mathrm{Cr}$, liver $>$ muscle $>$ gill for Fe and gill $>$ muscle $>$ liver for $\mathrm{Cd}$. The metal content determined in the three fish species is in the order: Catfish > Tilapia > Barbus in $\mathrm{Cd}, \mathrm{Co}, \mathrm{Cu}, \mathrm{Fe}, \mathrm{Pb}$ and $\mathrm{Zn}$ content in all tissues. Their Mn content is in order: Tilapia $>$ Catfish $>$ Barbus in muscle, Catfish $>$ Barbus $>$ Tilapia in gill, Catfish $>$ Tilapia $>$ Barbus in liver, $\mathrm{Cr}$ exist in the order: Catfish $>$ Tilapia $>$ Barbus in muscle and gill, Catfish $>$ Barbus $>$ Tilapia in liver whereas Ni exist in the order: Catfish $>$ Tilapia $>$ Barbus in muscle and liver and Catfish $>$ Barbus > Tilapia in gill.

\section{Exposure of fishes and humans with trace metals}

Bioconcentration factor (BCF) calculated (Table 4) is the highest in Catfish for all metals except for Mn which maximum in Tilapia. For remaining two fishes $\mathrm{BCF}$ in the order: Tilapia $>$ Barbus. BCF existence in low $(<250)$ level indicates, each fish species excrete trace metal after ingesting or do not consume in excess from water [19].

From hazard quotient (HQ) calculated (Table 5) and according to $[20,21]$ values found are in no hazard level $(<0.1)$ for all metals in the three fish species. Therefore, it is an indication for absence of any hazardous consequences on consumption of the fish species. HQ (Figure 2) is highest in Catfish for all metals except $\mathrm{Mn}$ and the least in Barbus. Therefore, trace metals exposure from eating catfish is higher than either of the two species.

\section{Statistical analysis}

Two-way ANOVA results confirmed that there was a significance difference in levels of trace metals between fish tissues and within tissues of different fishes (P-value $<0.05)$. However, multiple comparison by Post Hoc test at 95\% CL indicated absence of significant difference ( $\mathrm{P}$-value $>0.05$ ) between $\mathrm{Cu}$ and $\mathrm{Pb}$ in gills, $\mathrm{Cd}$ and $\mathrm{Pb}$; $\mathrm{Cd}$ and $\mathrm{Cr}$; $\mathrm{Co}$ and $\mathrm{Mn} ; \mathrm{Cu}$ and $\mathrm{Ni} ; \mathrm{Pb}$ and $\mathrm{Cr}$ in muscles and $\mathrm{Cd}$ and $\mathrm{Cr}$; $\mathrm{Co}$ and $\mathrm{Mn}$; $\mathrm{Pb}$ and $\mathrm{Ni}$ in livers.

\section{Comparisons of results}

Metals levels comparisons of present study with related works in

\begin{tabular}{|c|c|c|c|c|c|c|c|c|c|}
\hline \multirow{2}{*}{ Fishes } & \multicolumn{10}{|c|}{ BCF of each fish } \\
\cline { 2 - 12 } & $\mathrm{Cd}$ & $\mathrm{Co}$ & $\mathrm{Cu}$ & $\mathrm{Mn}$ & $\mathrm{Fe}$ & $\mathrm{Pb}$ & $\mathrm{Zn}$ & $\mathrm{Cr}$ & $\mathrm{Ni}$ \\
\hline Catfish & - & 2.97 & 4.77 & 4.44 & 41.76 & 2.81 & 12.86 & 5.07 & 2.18 \\
\hline Tilapia & - & 2.59 & 4.02 & 4.92 & 18.92 & 2.00 & 8.66 & 3.53 & 1.97 \\
\hline Barbus & - & 1.80 & 2.38 & 2.45 & 13.84 & 1.27 & 5.02 & 1.67 & 1.29 \\
\hline
\end{tabular}

Table 4: Bioconcentration factor of reservoir fishes muscle (catfish, tilapia and barbus).
Kubanni Reservoir and Aladja River of Nigeria indicate that except zinc and manganese all metals levels were lower in Tendaho Reservoir water (Table 6). Kubanni Reservoir has higher levels of all metals whereas Aladja River has higher levels of all compared metals excluding zinc and manganese as compared to study area. The Ethiopian Environment Protection Agency (EEPA) guide lines value comparisons with present study also revealed that the levels of manganese, iron, lead and chromium were higher and levels of copper and zinc lower in the study area as compared to safe guide line for aquatic organisms. This indicates that the presence of either natural or anthropogenic sources of manganese, iron, lead and chromium in the study area may affect aquatic organisms.

Metals level of present study in sediment compared with related works in Kowsar Reservoir of Iran and Aladja River of Nigeria indicated that all metals levels were higher in Kowsar Reservoir whereas levels of $\mathrm{Cd}, \mathrm{Fe}, \mathrm{Pb}, \mathrm{Zn}$ and $\mathrm{Ni}$ were lower in Aladja River as compared to Tendaho Reservoir water (Table 7). Aladja River has higher levels of manganese and chromium as compared to Tendaho Reservoir. The USEPA (2000) PEL guide lines value as compared with present study showed that all metal levels were below guide line in study area as compared to safe guide line for aquatic organisms. This indicated that amount of trace metals present around sediments of the reservoir pose no problem to aquatic organisms.

Fishes tissue metal levels comparisons with related work (Table 8). For Tilapia fish comparison with Awasa Tikurwuha and Aladja River of Nigeria indicate that all metals level excluding Co were higher in Tilapia of Tikurwuha whereas Aladja River has lower levels of all metals as compared to Tilapia from Tendaho Reservoir. Trace metals level in Catfish muscle of present study comparison with Aladja River of Nigeria indicates that levels of $\mathrm{Pb}, \mathrm{Cr}$ and $\mathrm{Ni}$ were higher in Aladja River whereas levels of Cd, Mn and Zn were higher in Tendaho Reservoir Catfish muscle. Comparison of the present study with the permissible limits set by WHO (1989) guideline showed that the levels of $\mathrm{Cd}, \mathrm{Cu}, \mathrm{Fe}, \mathrm{Pb}, \mathrm{Zn}$ and $\mathrm{Cr}$ were below the acceptable limits. However, $\mathrm{Mn}$ and $\mathrm{Ni}$ level was slightly higher than the permissible limit but the existence of these metals in acceptable limits according to the USFDA (1993) was shown in [22].

\section{Conclusions}

The analysis result with validated analytical method with acceptable accuracy, precision and quality control measures showed that excluding $\mathrm{Zn}, \mathrm{Mn}$ and $\mathrm{Co}$ (fish > sediment $>$ water) in metals distribution comparison of fishes with their environment exist in the order: sediment $>$ fish tissue $>$ water. This indicates that excluded metals taken by fishes more for their physiological functions as compared to other metals from their environment.

\begin{tabular}{|c|c|c|c|c|c|c|c|}
\hline \multirow{2}{*}{ Metals } & \multirow{2}{*}{ RfD } & \multicolumn{2}{|c|}{ Catfish } & \multicolumn{2}{|c|}{ Tilapia } & \multicolumn{2}{|c|}{ Barbus } \\
\hline & & $\operatorname{EDI}\left(x^{-06}\right)$ & $H Q\left(x E^{-06}\right)$ & $\operatorname{EDI}\left(x^{-06}\right)$ & $H Q\left(x E^{-06}\right)$ & $\operatorname{EDI}\left(\mathrm{xE}^{-06}\right)$ & $H Q\left(x E^{-06}\right)$ \\
\hline $\mathrm{Cd}$ & 0.001 & 3.00 & 0.003 & 2.00 & 0.002 & 2.00 & 0.002 \\
\hline Co & 0.100 & 0.40 & 0.040 & 0.30 & 0.030 & 0.20 & 0.020 \\
\hline $\mathrm{Cu}$ & 0.040 & 0.30 & 0.060 & 0.20 & 0.050 & 0.10 & 0.030 \\
\hline $\mathrm{Mn}$ & 0.140 & 0.40 & 0.030 & 0.40 & 0.030 & 0.20 & 0.020 \\
\hline $\mathrm{Fe}$ & 0.700 & 0.06 & 0.080 & 0.50 & 0.040 & 0.02 & 0.030 \\
\hline $\mathrm{Pb}$ & - & 7.00 & - & 5.00 & - & 0.30 & - \\
\hline $\mathrm{Zn}$ & 0.300 & 0.03 & 0.001 & 0.02 & 0.070 & 0.01 & 0.040 \\
\hline $\mathrm{Cr}$ & 0.003 & 8.00 & 0.030 & 5.00 & 0.002 & 3.00 & 0.050 \\
\hline $\mathrm{Ni}$ & 0.020 & 0.02 & 0.001 & 0.20 & 0.090 & 0.10 & 0.060 \\
\hline
\end{tabular}

Table 5: Estimated daily intake (EDI) and $\mathrm{HQ}$ of trace metals by consuming three commercially important fishes of Tendaho reservoir in Ethiopia $(\mathrm{RfD}=\mathrm{mg} / \mathrm{Kg} / \mathrm{day}$ and $\mathrm{EDI}=\mathrm{mg} \mathrm{kg}-1$ day-1). 


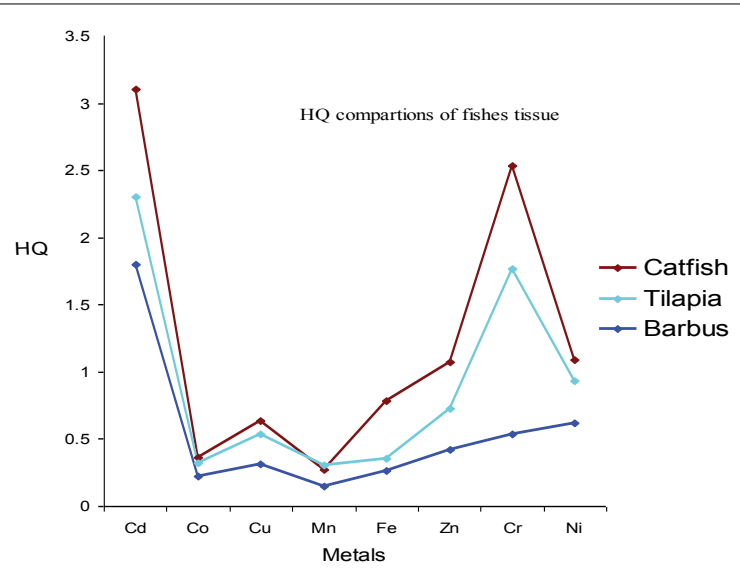

Figure 2: Hazard quotient comparisons for three fish species tissue.

\begin{tabular}{|c|c|c|c|c|}
\hline \multirow{2}{*}{ Metals } & \multirow{2}{*}{ PS } & \multicolumn{2}{|c|}{ Related works } & \multirow{2}{*}{$\begin{array}{c}\text { Guidelines } \\
\text { EEPA (2003) }\end{array}$} \\
\hline & & John et al. [35] & Abolude et al. [24] & \\
\hline $\mathrm{Cd}$ & $<M D L$ & 0.07 & 0.021 & 0.003 \\
\hline Co & 1.23 & - & 1.26 & - \\
\hline $\mathrm{Cu}$ & 0.53 & - & $0.88 \mathrm{t}$ & 2.0 \\
\hline $\mathrm{Mn}$ & 0.86 & $<0.01$ & 1.00 & 0.5 \\
\hline $\mathrm{Fe}$ & 1.32 & 2.47 & 2.36 & 0.3 \\
\hline $\mathrm{Pb}$ & 0.26 & 0.50 & 1.22 & 0.01 \\
\hline $\mathrm{Zn}$ & 2.51 & 0.84 & 0.11 & 5.0 \\
\hline $\mathrm{Cr}$ & 0.15 & 0.50 & 0.86 & 0.05 \\
\hline $\mathrm{Ni}$ & 0.95 & 4.82 & 1.61 & - \\
\hline
\end{tabular}

Table 6: Comparison of trace metals levels in water of present study with related works and guide line standards of surface water for protection of benthic organisms $(\mathrm{mg} / \mathrm{L})$.

\begin{tabular}{|c|c|c|c|c|}
\hline \multirow{2}{*}{ Metals a } & \multirow{2}{*}{ PS } & \multicolumn{2}{|c|}{ Related works } & Guidelines \\
\cline { 3 - 5 } & $\begin{array}{c}\text { John et al. } \\
{[\mathbf{3 5 ]}}\end{array}$ & $\begin{array}{c}\text { Karbassi et al. } \\
{[\mathbf{3 6}]}\end{array}$ & USEPA \\
\hline $\mathrm{Cd}$ & 1.03 & 0.97 & 5.0 & 3.53 \\
\hline $\mathrm{Co}$ & 2.59 & - & 11.3 & - \\
\hline $\mathrm{Cu}$ & 10.35 & - & 19.7 & 197 \\
\hline $\mathrm{Mn}$ & 3.28 & 4.95 & 256.7 & - \\
\hline $\mathrm{Fe}$ & 102.13 & 6.48 & - & - \\
\hline $\mathrm{Pb}$ & 5.78 & 0.25 & 42.7 & 91.3 \\
\hline $\mathrm{Zn}$ & 21.89 & 1.04 & 35.0 & 315 \\
\hline $\mathrm{Cr}$ & 2.52 & 5.0 & - & 90 \\
\hline $\mathrm{Ni}$ & 5.24 & 3.86 & 74.0 & - \\
\hline
\end{tabular}

Table 7: Comparison of trace metals levels in sediment of present study with related works and guide line for protection of benthic organisms (all in $\mu \mathrm{g} / \mathrm{g}$, dry weight).

\begin{tabular}{|c|c|c|c|c|c|c|c|c|c|c|}
\hline Fishes & $\mathrm{Cd}$ & Co & $\mathrm{Cu}$ & $\mathrm{Mn}$ & $\mathrm{Fe}$ & $\mathrm{Pb}$ & $\mathrm{Zn}$ & $\mathrm{Cr}$ & $\mathrm{Ni}$ & Sources \\
\hline \multirow{3}{*}{ Catfish } & 0.31 & 3.65 & 2.53 & 3.82 & 55.12 & 0.73 & 32.29 & 0.76 & 2.17 & PS \\
\hline & 0.20 & - & - & 1.50 & 18.01 & 1.00 & 10.80 & 0.80 & 5.00 & (1) \\
\hline & 1.0 & - & 30.0 & 1.0 & 100.0 & 2.0 & 100 & 50 & 1.0 & ${ }^{\star} \mathrm{PL}(3)$ \\
\hline \multirow{4}{*}{ Tilapia } & 0.23 & 3.18 & 2.13 & 4.23 & 24.98 & 0.52 & 21.74 & 0.53 & 1.87 & PS \\
\hline & 1.04 & $2.77 \mathrm{t}$ & 4.49 & 6.78 & 53.90 & 1.89 & 38.6 & - & 14.6 & (2) \\
\hline & $<0.01$ & - & - & 2.40 & 0.80 & 0.01 & 1.41 & 0.01 & 0.01 & (1) \\
\hline & 1.0 & - & 30.0 & 1.0 & 100.0 & 2.0 & 100 & 50 & 1.0 & "PL (3) \\
\hline \multirow{2}{*}{ Barbus } & 0.18 & 2.21 & 1.26 & 2.11 & 18.27 & 0.33 & 12.60 & 0.25 & 1.23 & PS \\
\hline & 1.0 & - & 30.0 & 1.0 & 100.0 & 2.0 & 100 & 50 & 1.0 & "PL (3) \\
\hline
\end{tabular}

Where: (1) = John et al., (2) = Kebede and Wondimu, (3) = Mokhtar et al., $\mathrm{PS}=$ Present study, ${ }^{*} \mathrm{PL}=$ permissible limit according to $\mathrm{WHO}, 1989$

Table 8: Comparison of trace metal levels in fish muscle of present study with related works and guide line standards for the safety of fish food consumers (all in $\mu \mathrm{g} / \mathrm{g}$, dry weight).
Regardless of the type of fish species, the levels of almost all metals were higher in detoxification organs (gill and liver) than muscle. This indicates that the rate of detoxification of trace metals from fishes body is higher than the rate of accumulation in their muscle. This is also in very good agreement with calculated low BCF and two-way ANOVA analysis results $(\mathrm{P}$-value $<0.05)$. Among fish species, the highest levels of major metals existed in Catfish as observed from two-way ANOVA analysis result $(\mathrm{P}$-value $<0.05)$ and the highest calculated $\mathrm{BCF}$ compared to other fish species. This may be due to carnivores feeding habit of the fish as seen during dissection, low sequestering tendency (higher BCF) of trace metals and more susceptibility of this species for trace metal pollutant compared to Tilapia and Barbus intremidus.

Comparison of results with related works indicated that the majority of trace metals from fish muscle and their environment of this study were lower than the others indicating that the area is not polluted by trace metal pollutants as much as those compared. On the other hand comparison results with guide lines showed that for water sample $\mathrm{Mn}, \mathrm{Fe}, \mathrm{Pb}$ and $\mathrm{Cr}$ were higher in the study area than [23-26]. This clearly indicates the presence of either natural or anthropogenic sources of $\mathrm{Mn}, \mathrm{Fe}, \mathrm{Pb}$ and $\mathrm{Cr}$ to the water body which may affect aquatic organisms.

Regarding customers' safety, absence of any trace metals hazardous exposure was observed. This was guaranteed by a low calculated HQ values and all metals were below the WHO (1989) and [26-39] guidelines safety limits. Although in this study there is no trace metal exposure of water, sediments, biota and fish consumers, due to rapid urbanization, industrialization and high degree of exposure of reservoir for aquatic pollutants needs continuous follow up and monitoring to avoid unexpected events like minamata disease.

\section{References}

1. Akiwumi F, Butler D (2008) Mining and environmental change in Sierra Leone, West Africa a remote sensing and hydrogeomorphological study. Environ Monit Assess 142: 309-318.

2. Lwanga M, Kansiime F, Denny P, Scullion J (2003) Heavy metals in Lake George, Uganda, with relation metal concentrations in tissues of common fish species. Hydrobiologia 499: 83-93.

3. Muohi A, Onyari J, Omondi J, Mavuti K (2003) Heavy metals in sediments from Makupa and Port-Reitz Creek systems: Kenyan Coast. Environ Int 28: 639647.

4. Alemayehu T (2000) Water pollution by natural inorganic chemicals in the central part of the main Ethiopian Rift. Ethiop J Sci 23: 197-214.

5. Gebremariam Z, Nicholas J (2003) Concentrations of heavy metals and related trace elements in some Ethiopian rift-valley lakes and their in-flows. Hydrobiologia 429: 171-178.

6. Kebede A, Wondimu T (2004). Distribution of trace elements in muscle and organs of tilapia, oreochromis niloticus, from Lakes Awassa and Ziway, Ethiopia. Chem Soc Ethiop 18: 119-130.

7. Uzairu A, Harrison G, Balarabe M, Nnaji J (2009) Concentration levels of trace metals in fish and sediment from Kubanni River, Northern Nigeria. Bull Chem Soc Ethiopia 23: 9-17.

8. Ekeanyanwu C, Ogbuinyi C, Etienajirhevwe O (2010) Trace Metals Distribution in fish the Tissues, Bottom Sediments and Water from Okumeshi River in Delta State, Nigeria. Ethiop J Environ Manage 3: 12-17.

9. IAEA (2003) Collection and preparation of bottom sediment samples for analysis of radionuclides and trace elements, IAEA, Austria. 3-4.

10. USEPA (1999) Sediment sampling. Field sampling guidance document numbe 1215 US. USEPA region 9 laboratory Richmond, California 5-6.

11. USEPA (2000) Guidance for assessing chemical contaminant data for use in fish advisories:Fish sampling and analysis, United States Environmental Protection Agency number 823R95007 3 $3^{\text {rd }}($ edn) Washington DC 186-190. 
Citation: Asefa W, Beranu T (2015) Levels of Some Trace Metals in Fishes Tissues, Water and Sediment at Tendaho Water Reservoir, Afar Region, Ethiopia. J Environ Anal Toxicol 5: 313. doi:10.4172/2161-0525.1000313

Page 6 of 6

12. Csuros M, Csuros C (2002) Environmental sampling and analysis for metals. Lewis publishers, USA 218-241.

13. USEPA (2003) Guidelines Establishing Test Procedures for the Analysis of Pollutants under Clean Water Act; Analysis and Sampling Procedures 318-324.

14. Skoog DA, West DM, Holler JF, Crouch SR (2004) Fundamentals of Analytical Chemistry, 8th (Edn) Brooks/cole, Canada P: 214-220.

15. Mitra S (2003) Sample preparation techniques in analytical chemistry vol 162. John Wiley \& Sons Inc Hoboken, New Jersey 7-30.

16. Gordon A, Demissie S, Tadesse M (2007) Marketing systems for fish from Lake Tana, Ethiopia: Opportunities for marketing and livelihoods.

17. AOAC (1999) Standard procedure for determination of moisture content.

18. Ali M, Iqbal F, Salam A, Iram S, Athar M (2005) Comparative study of body compositions of different fish species from brackish water pond. Int $\mathrm{J}$ Environ Sci Tech 2: 229-232.

19. Hussein A, Manal M, Mona M (2011) Effect of Exposure to Mercury on Health in Tropical Macrobrachium Rosenbergii. Life Sci J 8: 154-163.

20. Lemly A (1996) Evaluation of the Hazard Quotient Method for Risk Assessment of Selenium, Ecotoxicol Environ Safety 35: 156-162.

21. Onsanit S, Ke C, Wang X, Wang K, Wang W (2010) Trace elements in two marine fish cultured in fish cages in Fujian province, China. Environ Pollut 158: 1334-1342.

22. Raja P, Veerasingam S, Suresh G, Marichamy G, Venkatachalapathy R (2009) Heavy Metals concentration in four commercially valuable marine edible fish species from Parangipettai coast, South East coast of India. Int J Animal and Vet Adv 1: 10-14

23. EEPA (2003) Guideline Ambient Environment Standards for Ethiopia. Environmental Protection Authority and United Nation Industrial Development Organiztion, AA. pp 4-16.

24. Abolude D, Davies O, Chia A (2009) Distribution and Concentration of Trace Elements in Kubanni Reservoir Northern Nigeria. Environ Earth Sci 1: 39-44.

25. Agbozu I, Ekweozor I, Opuene K (2007) Survey of Heavy Metals in the Catfish SynodontisClarias. Int J Environ Sci Tech 4: 93-97.

26. Bahnasawy M, Khidr A, Dheina N (2011) Assessment of heavy metal concentrations in water, plankton, and fish of Lake Manzala, Egypt. Turk J Zool 35: $271-280$.
27. Brown R, Milton M (2005) Analytical techniques for trace element analysis: an overview. Trends Anal Chem 24: 266-274.

28. Bulska E (2001) Analytical advantages of using electrochemistry for atomic spectrometry, Pure Appl Chem 73: 1-7.

29. Bury N, Walker P, Glover C (2003) Review nutritive metal uptake in teleost fish. J Exp Biol 206: 11-23.

30. Crafford D, Avenant A (2011) Uptake of selected metals in tissues and the organs of Clarias gariepinus (sharptooth catfish) from the Vaal River System Chromium, copper, iron, manganese and zinc. Water SA 37: 181-200.

31. Gebremariam Z, Desta Z (2002) The chemical composition of the effluent from Awassa Textile Factory and its effects on aquatic biota. Ethiop J Sci 25:263-274

32. Gobas F, Wilcockson J, Russell R, Haffner G (1999) Mechanisms of biomagnification in fish under laboratory and field conditions. Environ. Sci. Technol33:133-141.

33. Hargrave B, Phillips W, Vass P, Welch H, Siferd T (2000) Seasonality in bioaccumulation of organ chlorines in lower tropic level in the Arctic marine biota. Environ Sci Technol 34: 980-987.

34. Harris D (2007) Quantitative Chemical Analysis, $7^{\text {th }}$ (Edn) Freeman WH and Company, New York 82-83.

35. Johan N, Orish E, Isaak O (2010) Heavy Metal Levels in Muscles of Some Fish Species from Aladja River; Warri, Nigeria: A Public Health Concern. Adv Environ boil 4: 125-130.

36. Karbassi A, Torabi F, Ghazban F, Ardestani M (2011) Association of trace metals with various sedimentary phases in dam reservoirs. Int J Env Sci Tech 8:841-852

37. Mokhtar M, Aris A, Munusamy V, Praveena S (2009) Assessment levels of heavy metals in Penaeus Monodon and Oreochromis Spp in selected aquaculture ponds of high densities development area. Eur J Sci Re 30: 348-360.

38. Muhammad A, Khan A, Shakoori A (2009) Trace Metal Accumulation in the Liver of an Endangered South Asian Fresh Water Fish Dwelling in Sub-Lethal Pollution. Pakistan J Zool 41: 35-41.

39. Uysal K, Emre Y (2011) Bioaccumulation of copper, zinc, manganese, iron and magnesium in some economically important fish from the Western shores of Antalya. Life Sci Biotechnol 1: 95-102. 